\title{
Guest research facilities at the Biologische Anstalt Helgoland: past and present
}

\author{
J. Harms * \\ Biologische Anstalt Helgoland (Meeresstation); D-27483 Helgoland, Germany
}

\begin{abstract}
The Biologische Anstalt Helgoland (BAH) offers unique possibilities for research and education in marine sciences in the southern part of the North Sea. Besides its own research duties, the Institute provides research facilities and technical assistance for guest scientists, assists in the teaching and education of university student groups, and conducts its own courses. The Institute further supplies universities and research institutions on the mainland with marine organisms. The marine station on Helgoland has 14 laboratories, with a total of 32 working places available for guest scientists. The Wadden Sea Institute in List on the island of Sylt offers 6 laboratories with a total of 18 working places. Furthermore, laboratory classrooms are located on Helgoland and in List for 50 and 20 participants, respectively. For the convenience of the guest researchers staying at the $\mathrm{BAH}$, guest-houses are run on Helgoland (Arthur-Hagmeier-Haus, Wilhelm-Mielk-Haus) und in List (Adolf-Bückmann-Haus). Guest researchers have been welcome since the founding of the Institute in 1892. Heincke gave a brief report on the activities of the first visitors from 1892 to 1897 . Only sporadic reports are available for the first 60 years of this century. Guest scientists and their activities have only been recorded in detail in the annual reports of the BAH since 1962. The number of researchers and the length of their visits have increased continuously since 1962. The research facilities on Helgoland, in List and Hamburg have been modernized during the last 20 years. In 1971 , four modern laboratories for guest researchers could be opened on Helgoland with financial support of the German Research Foundation (DFG). The number of guest researchers in List and Hamburg increased after the completion of new buildings in 1979 and 1982. The recent increase in research activities by guest scientists is due to numerous students, from many different universities, using the superb research facilities to do their Masters thesis, or Ph.D. Guest researchers and students either perform their own research or cooperate with scientists of the BAH.
\end{abstract}

The island of Helgoland is situated some $50 \mathrm{~km}$ away from the nearest mainland. Therefore, the marine environment around Helgoland displays an offshore character, which is for the major part of the year under the influence of North Sea water bodies (Martens, 1978). Helgoland is the only "marine" island and the only natural hard bottom substrate in the southern North Sea. More than 150 macroscopic algae (Kornmann \& Sahling, 1983a, b) and 700 macrobenthic organisms (Harms, 1993) can be found around Helgoland. Compared with the surrounding soft bottom habitats, the rocky substrate of Helgoland is like an oasis in a desert. This species richness was one of the reasons why scientists were already coming to Helgoland when it belonged to the English (Hagmeier, 1990). In 1831, a book by H. C. Trede (pharmacist on Helgoland), about Macroalgae, was published by Hoffmann \& Campe in Hamburg. In 1835, Professor C. G. Ehrenberg

- Present address Forschungszentrum Jülich, Projektträger BEO, Bereich Meeresforschung, Seestraße 15, D-18119 Warnemünde, Germany

(c) Biologische Anstalt Helgoland, Hamburg 


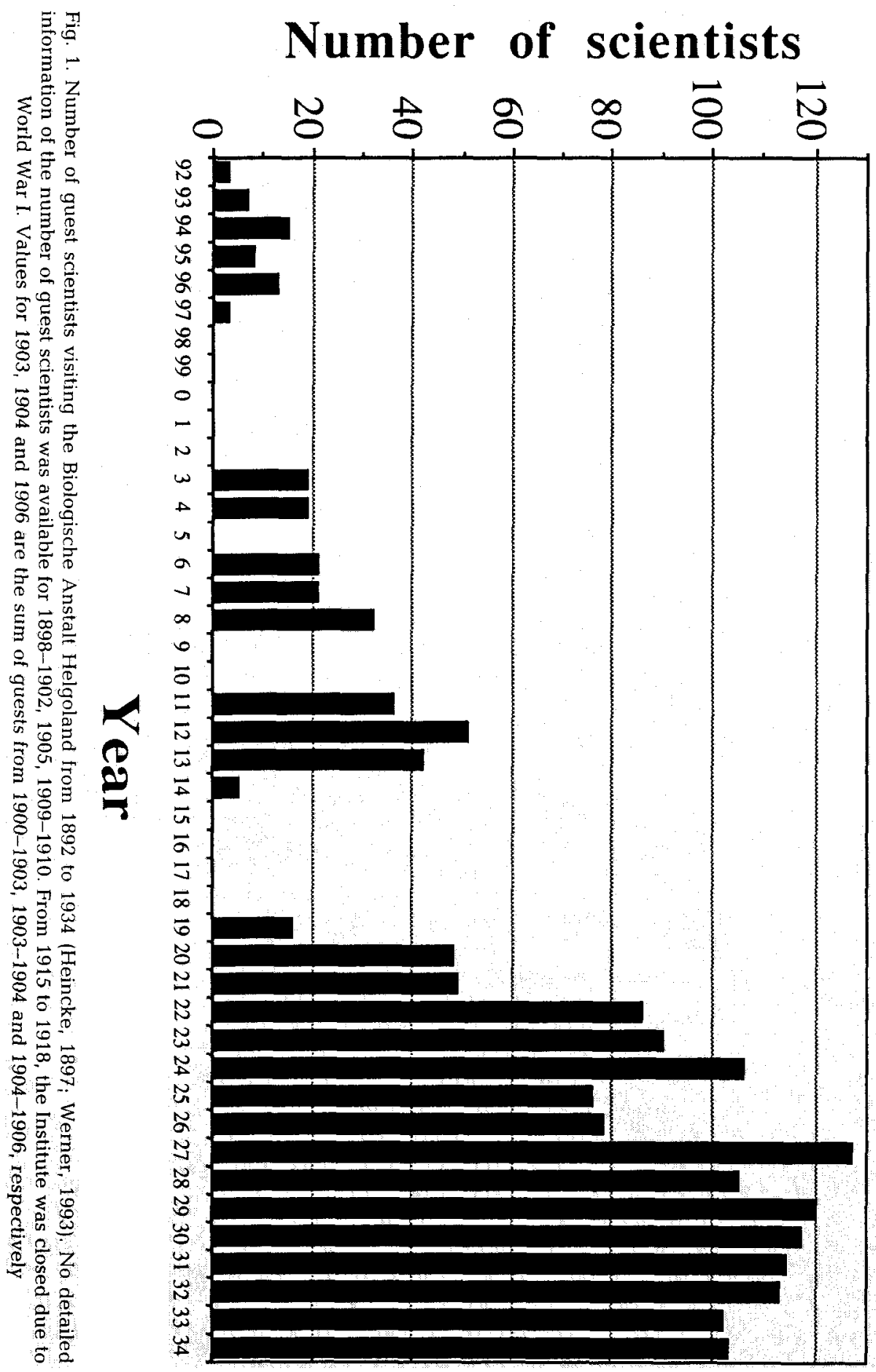


discovered the organism responsible for marine luminescence in the North Sea (Noctiluca miliaris). Professor Johannes Müller had visited Helgoland since 1845 to study plankton. In 1854 he was accompanied by Ernst Haeckel, who was fascinated by the marine organisms. A photograph from 1865 (see Hagmeier, 1990) shows participants of a marine excursion to Helgoland (Prof. Dohrn, Dr. Salverda, Dr. Greef, Dr. Marchi, Prof. Haeckel). These early activities and successful studies, especially in the field of developmental biology and plankton research, led to the foundation of the Biologische Anstalt Helgoland in 1892 (see Werner, 1993).

To supply research facilities for "ambulante Gelehrte". (itinerant academics) was the first point on the list of duties of the newly-founded Institute (see Wiss. Meeresunters. [Abt. Helgoland] 1893: 1; p. 3). The second point was the organization of student courses and supply of research material for institutions on the mainland. Up to the present time, the supply of research facilities for guest researchers is one of the major duties of the Biologische Anstalt Helgoland. This paper will give a general overview about these activities; more detailed information about research facilities is given in Heincke (1894, 1897, 1905, 1906, 1918), Mielck (1925, 1926, 1930), Hagmeier $(1935,1939,1952)$ and Bückmann (1959).

In the beginning, there was not enough money to build a modern institute immediately. An old Logirhouse (lodging-house) close to the old post office was the first building of the new Institute (Photodokumentation, see Wiss. Meeresunters. [Abt. Helgoland] 1893: 1 ; p. 6). The two-storey house had 19 rooms in total (Heincke, 1894). 2 rooms were available for 4 "itinerant academics". A small aquarium room (Photodokumentation, see Wiss. Meeresunters. [Abt. Helgoland] 1893: 1; p. 8) was located in the cellar. The working-places for the visiting guest researchers were equipped with dissection instruments and drawing utensils similar to the zoological station in Naples (Heincke, 1894). Later (in 1897) the old post office was bought by the Institute, increasing the workingplaces for guest researchers to 7 or 8 (Heincke, 1897).

The acceptance of the new research facilities for guest scientists during the first years was lower than expected (Fig. 1). Possible reasons were given by Professor Heincke in his second report (Heincke, 1897). Firstly, there was an increase of research institutes along the European coasts at that time, coinciding with a decline in the number of students interested in marine biology. Heincke wrote that the limitations of aquarium facilities might have been the major reason why only a few zoologists came to Helgoland during the first years. These difficulties were solved after the construction of a new aquarium in 1902 (see Schultheiß, 1988, p. 82), which was made possible by a donation by $M$. Oppenheim (Heincke, 1905).

During the years that followed, the Institute expanded more and more and, finally, in 1914 more than 14 different houses belonged to it (Heincke, 1918), increasing the places for visiting research workers to 16 . A major problem for guest researchers were the high living expenses on the island. Heincke (1918) mentioned that the costs for coming to Helgoland were too high, especially for young scientists, - although the Institute managed to reduce the cost for the ferry, health-tax and entrance fee for the baths by half. These problems have not changed very much recently. The cost of living on Helgoland is still higher than on the mainland, except for a few duty-free products.

The wide-spread, small buildings of the Institute were finally replaced by one large one (Schultheiß, 1988; p. 88), constructed during a twelve-year period, from 1925 to 1937 
(Hagmeier, 1939; Bückmann, 1959). The new building offered 20 working-places for visiting research workers. Furthermore, there was a modern lecture-room available for 32 participants and a room equipped with running seawater for the cultivation of marine organisms. Unfortunately the new building was destroyed at the end of World War II (Rickmers et al., 1986; p. 62).

A first summary of the activity of visiting researchers from 1893 to 1897 was given by Heincke $(1894 ;$ 1897). The information appears here in more detail (Table 1), because Werner (1993, p.121) wrote that there was no information available for 1892-1896. During these first five years, 44 scientists visited the Institute (Table 1), some of them more than once. The acceptance of the research facilities in these early years was comparable to the response in the other newly-founded institutes in Plymouth and Bergen (Heincke, 1897). Only the station in Naples, had higher numbers of guests. The research activity was mainly concentrated on morphological, taxonomic and physiological studies of marine organisms. Bird watchers also came to the Biologische Anstalt Helgoland in the early years. By 1893, a woman (J. von Meyer-Petersburg) had already visited the newly-founded institute; unfortunately no information about her subject of interest is available. In 1896, Professor O'Grady from the United States worked for a month on her research concerning the fertilization of Echinoderm eggs on Helgoland. Heincke gave a second summary of the activity of guest researchers in 1917 (Heincke, 1918). During the first 21 years of its existence, the Institute was visited by 470 scientists $19 \%$ of them coming from foreign countries, especially from Austria, Russia, the United Kingdom and the United States. After World War I, during which time the Institute was closed, the activity of guest researchers on Helgoland steadily increased. No complete records are available about the topics of the research activities of guest scientists between 1900 and 1930; unfortunately the annual reports by Heincke $(1905,1906)$, Mielck (1925, 1926, 1930), Hagmeier (1934, 1939, 1951) and Bückmann (1959) do not mention any activities of guest researchers. The available information about guest researchers and their activities from 1897 until 1945 was found by chance in some publications that are summarized by Werner (1993, pp. 126-128).

Professor Hagmeier (director of the Institute from 1930-1955) had, already in 1948, reorganized working facilities in List on the island of Sylt, where the Biologische Anstalt Helgoland had run a small station since 1924 (see Wiss Meeresunters. [Abt. Helgoland] 1927: 16, 6: p. 51) for the cultivation of oysters and ecological studies of the Wadden Sea (Hagmeier, 1951). The oyster station, which, in 1937 was transferred to the peninsula Ellenbogen on the island of Sylt, was not destroyed during World War II, therefore, scientific activities could be reorganized in List immediately after the war (Bückmann, 1959). The first student courses were already being held in 1948. In 1949, more than 170 students and sientists visited the station in List, demonstrating the enormous interest in studying the marine environment (Bückmann, 1959). Until the reconstruction of a new Institute on Helgoland in 1959, all activities were based in List. Research activities in List were reorganized by $\mathrm{O}$. Kinne, the director of the BAH from 1962 to 1984 , which led to the construction of new laboratories in 1972 and 1979. Nowadays, seven laboratories with 18 working places are available for guests coming to the Wadden Sea Institute.

Laboratories and the aquarium on Helgoland were re-opened in 1959 (Bückmann, 1959). Again, the supply of research facilities for guest scientists was one of the major duties of the "Meeresstation" on Helgoland. The laboratories available to guest research- 
Table 1. Name and activity of guest researchers visiting the Biological Station on Helgoland between 1892 and 1897. ' Results of the research activity are published (Heincke, 1897)

Des. Arts, stud. oec., Hamburg. 4.-5. 9. 1893.

Prof. Askenasy - Heidelberg. 14. 8.-14. 9. 1896 -Meeresalgen.

Dr. C. Graf Attems - Wien. 1. 9.-17. 10.1894-Rhabdocoele Turbellarien '.

Prof. Ballowitz-Greifswald. 14. 8.-3.9.1895-Elektrisches Organ der Rochen * 9.-26. 9. 1896 Elektrisches Organ der Rochen *

Dr. Ph. Barthels - Königswinter. 17.-24. 4. 1896 - Histologie des Oesophagus von Seevögeln * Dr. med. Behmer, Marine Stabsarzt, Helgoland 1897.

A. Bethe, cand. med., München, 27, 7.-29. 8. 1894 - Nervensystem der decapoden Crustaceen *. Bottemanne, stud. rer. nat., Bergen op Zoom. 24. 8.-11. 10. 1895.

Prof. Dahmes - Berlin. Frequently between 1893 and 1897 - Geologische Studien über Helgoland.

Dr. G. Duncker, cand phil., Hamburg. 14. 8.-18. 9. 1893 -Variation bei Plattfischen* .

Prof. Ehlers - Göttingen. 15. 8.-6. 9.1893-Polychaeten. 12. 8.-1. 9. 1894 -Polychaeten, Pedicellinen.

Dr. med. K. Escherich - Regensburg. 7.-25. 9. 1896.

Dr. Gottsche-Hamburg. Frequently between 1893 and 1897 . - Geologische Studien über Helgoland.

Prof. Dr. O. Hertwig-Berlin. 14.-18. 5. 1894 - Echinodermen-Eier.

Hecht, cand. pharm., Nürmberg. 18. 7.-29. 9. 1894.

Dr. C. Hoffbauer - Wernigerode. 14. 3.-3. 7. and 18. 10-16. 12. 1893 - Käfer von Helgoland.

21. 1.-27. 7. and 20. 10.-20. 12. 1894 -Ovarium der Knochenfische. 27. 6.-3. 7. and

12. 8.-20. 12. 1895 - Fischpräparate. 10. 1.-1. 4. 1896 - Fischpräparate.

B. Issatschenko-Petersburg. 13-19. 8. 1895 - Meeresalgen.

Dr. P. Knuth - Kiel. 8.-12. 7. 1895 - Landflora von Helgoland *

Prof. W. Krause - Berlin. 23 -29. 8. 1894 - Retina der Haie.

R. Lauterborn, cand. rer. nat., Heidelberg. 16. 8,-18. 9. 1893 -Protozoen und Rotatorien *

Oscar Levy, stud. med., Berlin. 3.-15. 8. 1896.

Dr. H. Lohmann - Kiel. 22--25. 8. 1892 - Halacarinen.

Prof. Dr. Lotsy, Johns Hopkins University Baltimore. 16. 8.-5. 9. 1894 - Florideen ${ }^{*}$.

Dr, med. Martin, Marine Stabsarzt, Helgoland. 22. 6.-1. 8. 1896.

Dr. med. Martini, Kreisphysikus, Helgoland. 1896.

Frl. J. von Meyer-Petersburg. July 1893.

Dr. med Mewius, Kreisphysikus, Helgoland 1894, 1895. - Bakteriologische Studien.

Prof. Möbius - Berlin. 8.-12. 8. 1892 - Tiere der Helgoländer Austernbank

Prof. Dr. Morgan - Bryn Mawr, America. 24. 6.-28. 8.1894-Befruchtungs- und Entwicklungsvorgänge an Eiern von Fischen und Echinodermen *.

L. Neidert, stud zool, Würzburg. 19. 7.-15. 9. 1894 1.-28. 8. 1896-Geschlechtsorgane von Amphioxus und Cirripedien.

Korvetten-Kapitän Neitzke - Wilhelmshaven, 26. 2.-10. 3. 1897.

Prof. O'Grady - Vassar College, NY., America, 6. 8.-7.9.1896-Befruchtungsvorgänge an

Echinodermen-Eiern.

Dr. F. Römer-Jena. 20. 8.-11. 9.1894.

H. Sandstede - Zwischenahn. June 1892 - Flechten von Helgoland '

Dr. Schenk-Bonn. September 1895 -Meeresalgen.

Dr. M. Schmidt - Oldenburg i. Gr 24, 9,-2, 10. 1894 Diatomeen.

Dr med. Senf, Marine Assistenzarzt, Wilhelmshaven. 26. 2,-10,3 1897

A Sokolowsky - Zürch $13,-17.8 .1896$ - Amphipoden von Helgoland.

Dr. J. Thiele-Dresden. 9. 7,-2.8.1894-Mollusken.

Dr. R. Timm-Hamburg, 24.-28, 7 1893-Copepoden:

Dr. Valkenier Suringar-Leiden. 6.-14.9. 1896.

Dr, W. Weltnet - Berlin. 7.-27,9,1894-Spongien, Cirripedien, Süßwasserfauna *. 1895 .

R. Woltereck, stud, rer. nat, Freiburg i, Br, 23, 8, -29, $9,1896$.

Prof. H. E. Zlegler - Freiburg i. Br. 10 8.-10.9. 1895 - Eierentwicklung von Ophiothrix * 


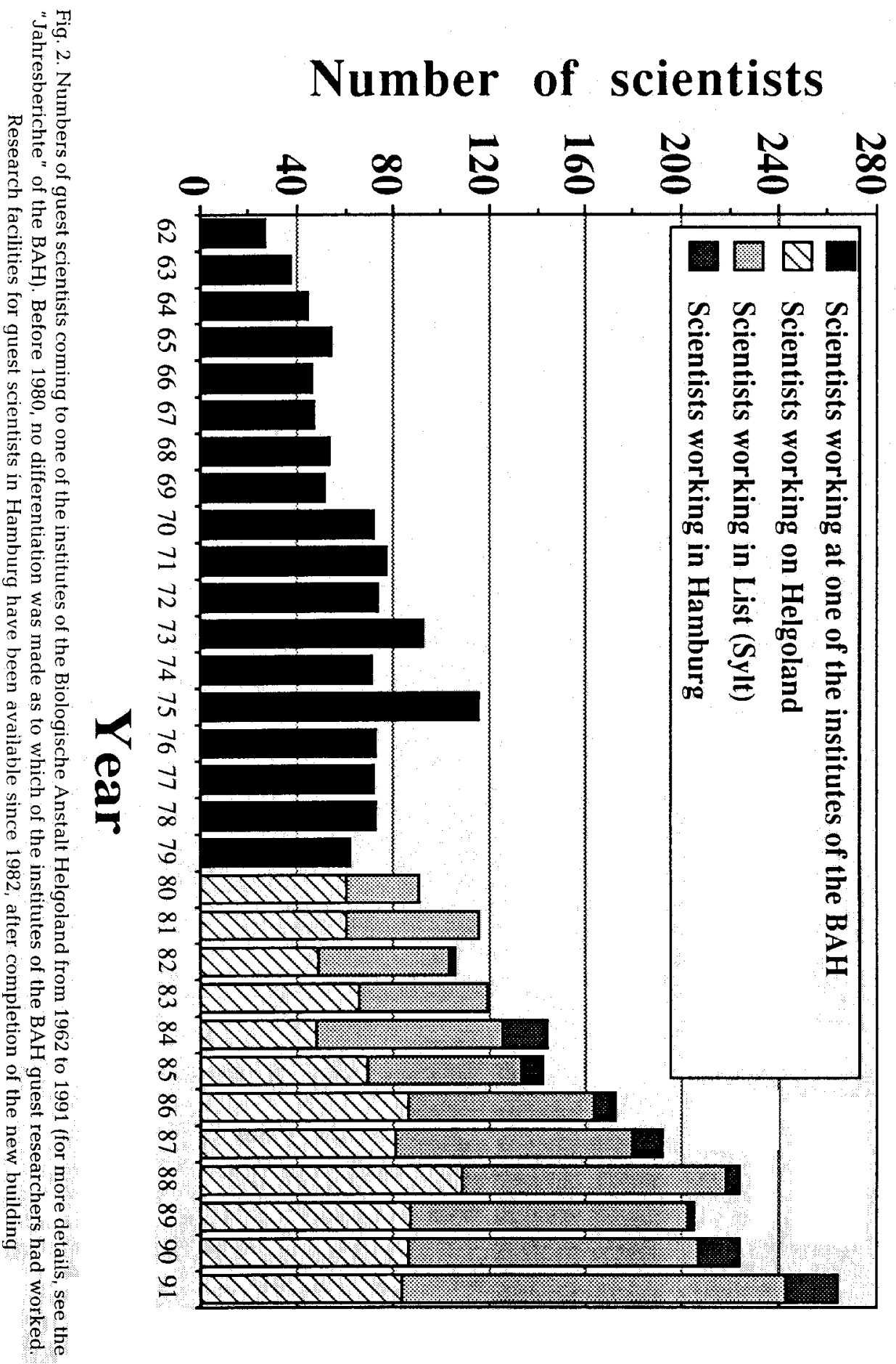


ers were equipped with modern technological apparatus with the financial help of the German Academic Research Foundation (DFG). These working places were at that time rented either by the Ministry for Cultural Activity of one of the states of the Federal Republic of Germany, or by the DFG and the Max-Plank Association (Bückmann, 1959). Scientists who wanted to work on Helgoland had to ask one of these organizations for a working place. The costs were $1500 \mathrm{DM}$ a year or 6,50 DM a day. Detailed descriptions and graphical illustrations of the laboratories are given by Bückmann (1959). Kinne (1971) gave an excellent overview of the working facilities for guest researchers at the end of the 'sixties. At that time, three working-places were available in List on Sylt and 15 on Helgoland. Accomodation for students and scientists have been available on Helgoland since 1960 in the "Arthur-Hagmeier-Haus", and since 1968 in the "Wilhelm-MielkHaus", which was built with the financial help of the "Volkswagenstiftung". The "AdolfBückmann-Haus" in List on Sylt was modernized in 1979, when major reconstruction for a new laboratory building for guest researchers was finished (Annual Report, 1979). This accomodation has often been booked out in recent years, especially in spring and summer, so more and more scientists have to be rejected because of the limited reasonably-priced accomodation. Private accomodation is, like in early times (especially for students and scientists from overseas) too expensive, because both islands are important holiday resorts.

The last modernisation of the facilities for guest researchers was undertaken on Helgoland in 1972, with the financial help of the DFG, which spent 1.9 Million DM in total for new equipment of four laboratories and for the employment of technicians and one scientist, who looked after the guest scientists. This was the foundation of the new division "Gastforscher Betreuung". at the Biologische Anstalt Helgoland, which is responsible for the supply of equipment and gives all possible help to guest scientists. Well known scientists were responsible for the acquisition of the new laboratories: for the Histology Laboratory it was Professor Siewing. The laboratory for electrophysiological studies was equipped by Professor Hensel, the laboratory for biochemistry and physiology by Professor Karlson, and for photophysiology by Professor Nultsch (for more details, see Annual report, 1972). These scientists were closely related to the Biologische Anstalt Helgoland, all of them used the research facilities regularly themselves, or sent students. With the opening of the "Experimentell ökologisches Laboratorium" in 1976, the institutes on Helgoland now can supply a total of 32 working places for guest scientists.

Statistics of the numbers of guest researchers coming to one of the institutes of the Biologische Anstalt Helgoland have been available since 1962 (Fig. 2). The numbers of guest scientists increased continously, reaching maximum levels in recent years. In the late 'sixties, discussions with the DFG (the German Academic Research Foundation) started - to reorganize and modernize the research facilities at the marine station on Helgoland (Annual Report, 1968, 1969, 1970; Kinne, 1971). During this time, scientists often were rejected because working facilities were booked out; the same was true for student courses. This discussion finally led to the aforementioned modernization of the Institute. Since 1973, with the change of the Institute to the "Ministry of Research and Technology", research facilities are supplied without any additional costs to the visiting scientists. The increase of the activity of guest researchers since the late seventies is caused more and more by an increase of students using the facilities at one of the institutes of the Biologische Anstalt Helgoland to do their diploma or dortoral thesis 


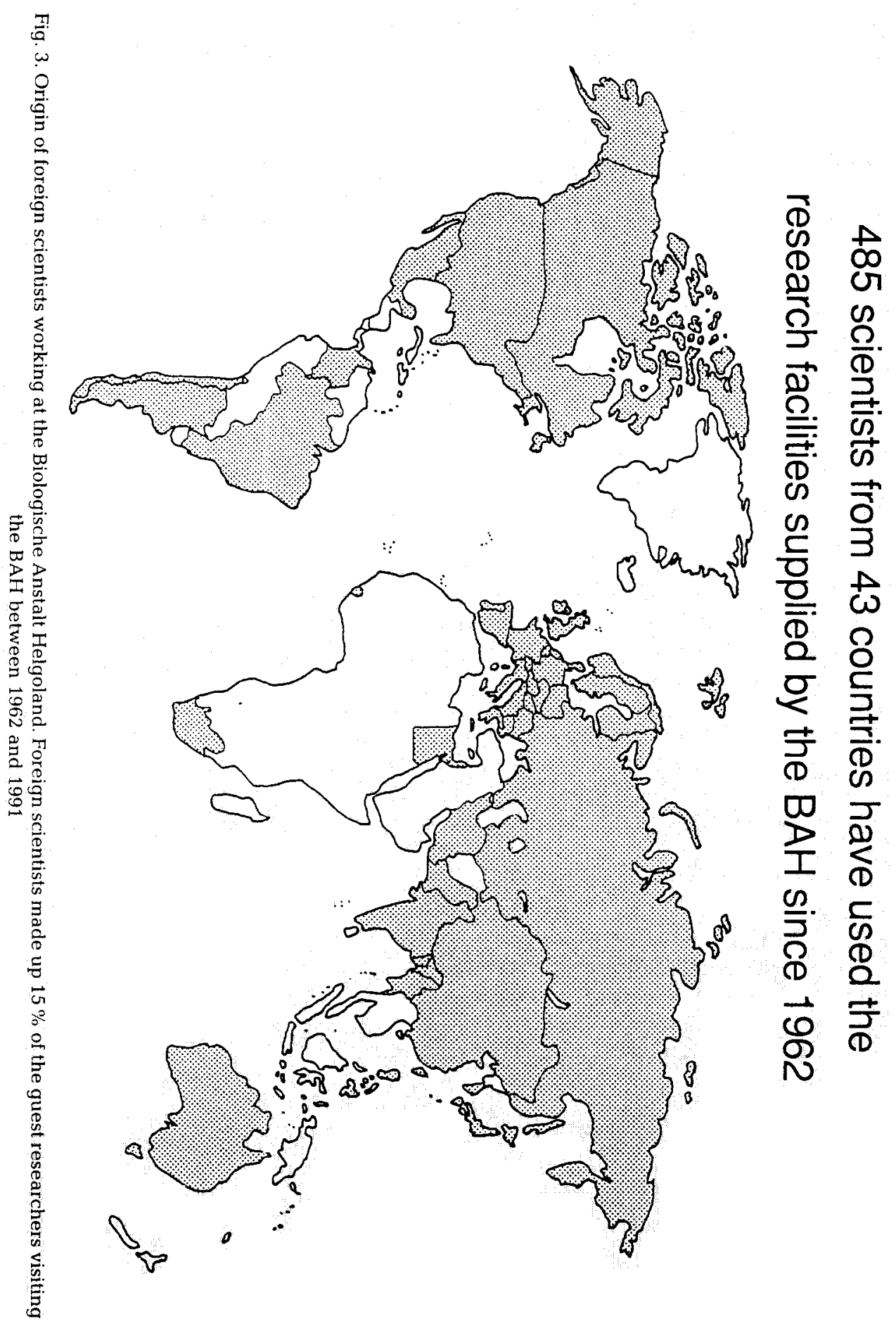


Furthermore, there was a drastic increase in the number of scientists going to List after the completion of new buildings in 1972 and 1979. After the opening of the new central building in Hamburg in 1982, guest scientists began to go also to Hamburg to cooperate with scientists working there. In total, 3152 scientists visited the institutes of the Biologische Anstalt Helgoland since 1962 (up to 1991). 485 scientists (15\%) came from 43 foreign countries, mainly from Europe, America and Asia (Fig. 3). So far, only a few scientists, have come from Africa.

Student courses have been held at the Biologische Anstalt Helgoland since 1920 (Fig. 4). After World War I, the Institute got a new building (Rickmers \& Woosnam, 1992; p. 65) from the Navy, in the harbour region (close to the position where we nowadays find the "Heincke Halle"), which was ideal for student courses. Statistics about the numbers of participants are given by Werner (1993). During these earlier times, most of the student courses were directly organized by the Biologische Anstalt Helgoland. Today, about 1000 students each year either come to Helgoland or List to study the marine environment (Fig. 5). Students find ideal requirements for doing studies of marine organisms in their

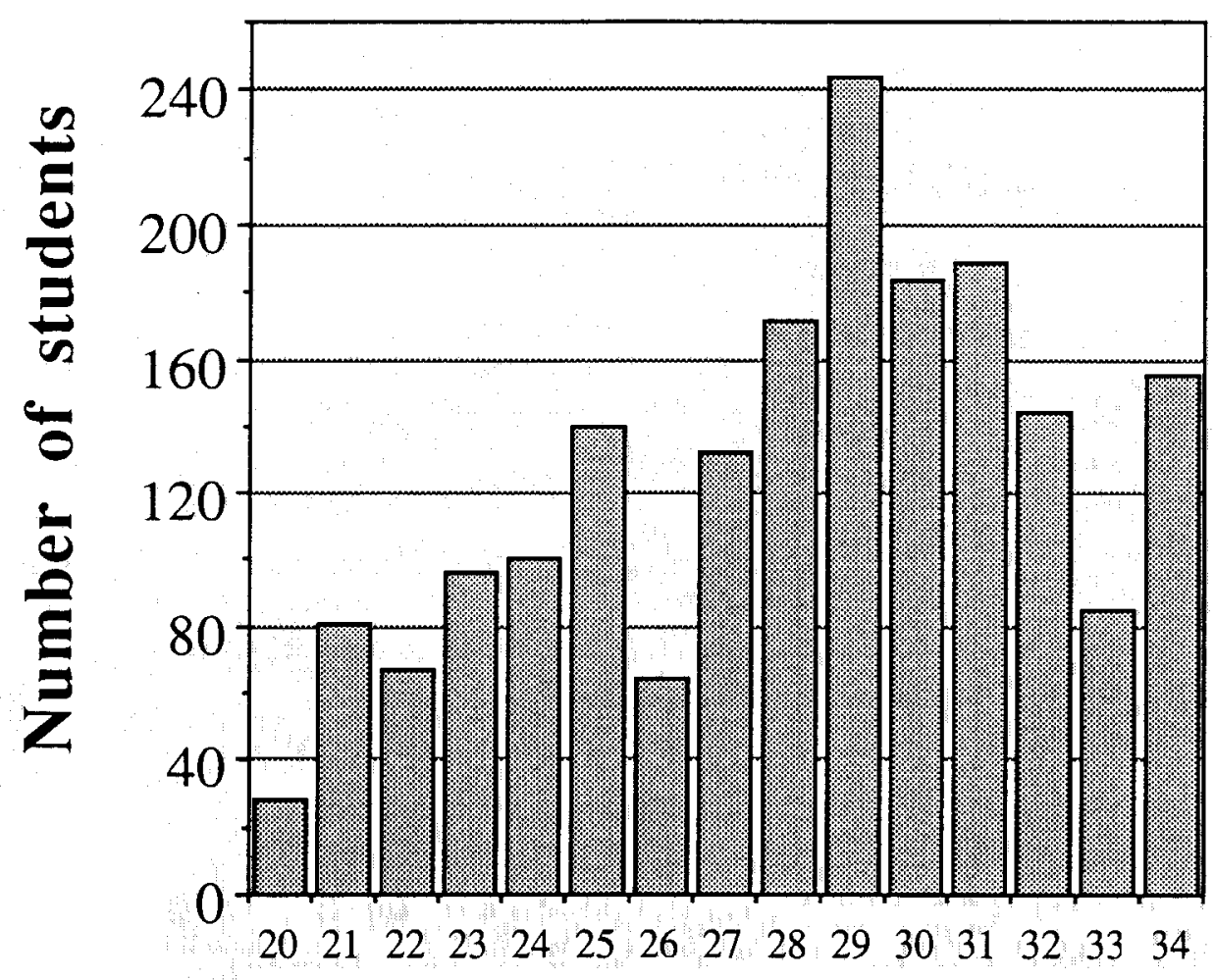

\section{Year}

Fig. 4. Numbers of students participating in lecture courses held at the Biologische Anstalt Helaoland from 1920 to 1934 (Werner. 1993) 
Number of students

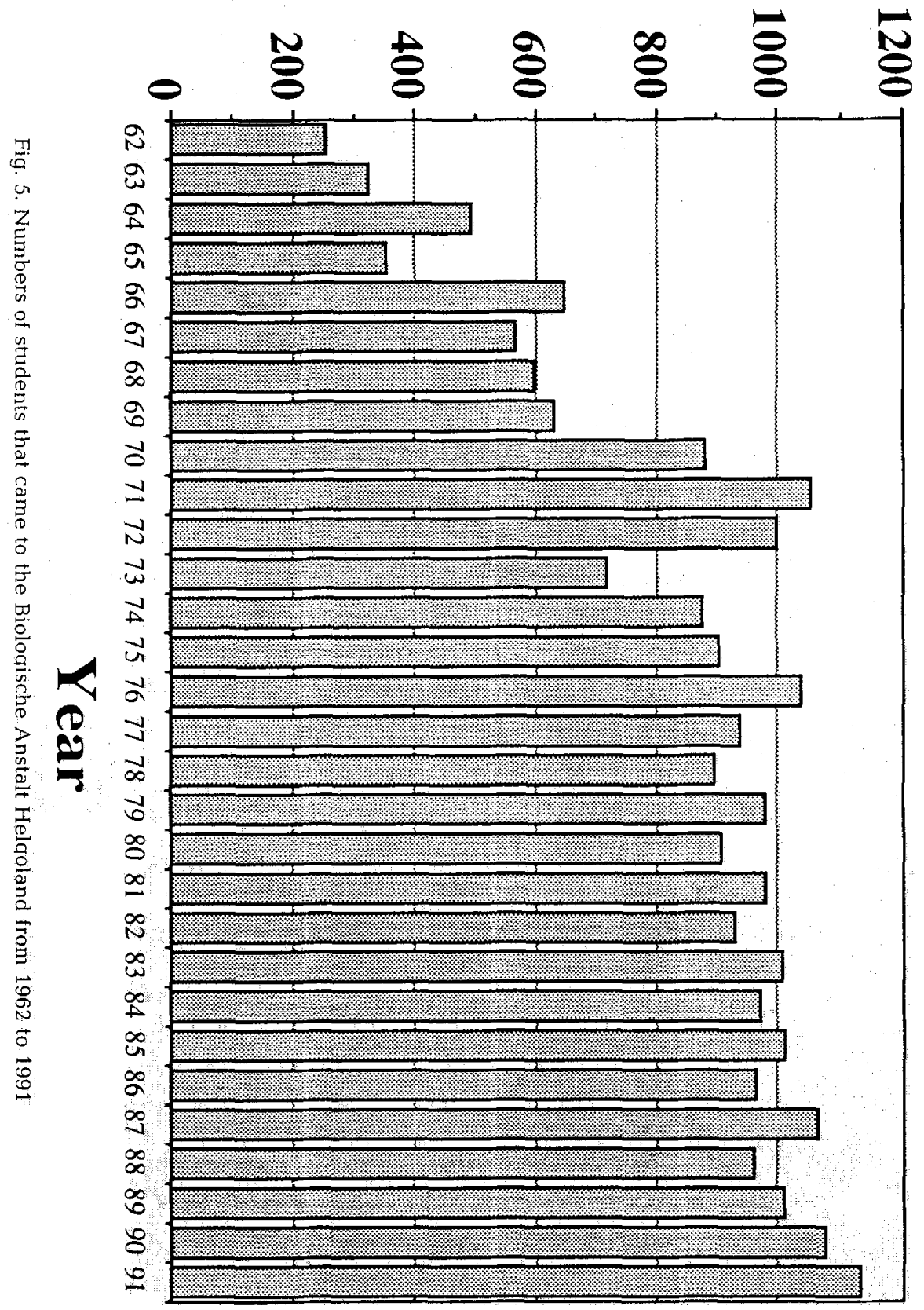


natural habitat. Laboratory class-rooms are located on Helgoland and in List, for 50 and 20 participants, respectively. The course rooms are well equipped and students find ideal conditions to study marine organisms in detail. Most student courses are run by the Universities themselves. The Biologische Anstalt Helgoland only runs a few special courses - and two general marine biology courses in the summer.

Brochures with all the necessary information on how to apply for working facilities at the Biologische Anstalt Helgoland are available on request. In 1992, the Institute had its hundredth anniversary. Now, two years later, major organisational changes for the BAH are being discussed within the Ministry of Research and Technology. It is to be hoped that guest researchers and students will also, in the future, find similarly good research facilities as in the past, when coming to the laboratories on Helgoland, List or in Hamburg. In my opinion, it is time for a major new input into the modernization of the laboratories. Special equipment is needed for modern fields in biology, such as genetic and molecular biology. Life originated in the sea, which has offered constant living conditions for long periods. Marine organisms, which did not have to develop special adaptations like organisms living in fresh water or on land, are still relatively simply organized. Therefore, they are especially favourable subjects for the detection of principle rules, and for basic research in modern areas of biology. The Biologische Anstalt Helgoland has a long tradition in supplying research facilities to universities and other institutes. The supply of modern equipment and technical assistance both was, and will be, the basis for the successful research activities of visiting scientists at the Biologische Anstalt Helgoland.

Acknowledgements. I am specially thanktul to U. Alexander, without whose help this publication would have not been possible. I am further grateful to I. Renckhoff, B. Sysoew and W. Sisolewsky for their assistance in literature research and literature supply. My thanks are also due to two anonymous referees for constructive comments on an earlier draft of the manuscript.

\section{LITERATURE CITED}

Bückmann, A., 1959. Die Wiedereröffnung der Biologischen Anstalt Helgoland auf der Insel Helgoland. - Helgoländer wiss. Meeresunters. 7, 1-55.

Hagmeier, A., 1934. Die Arbeiten der Biologischen Anstalt auf Helgoland in den Haushaltsjahren 1930-1933. - Ber dt. wiss. Kommn Meeresforsch. 7, 147-150.

Hagmeier, A., 1939. Die Arbeiten der Biologischen Anstalt auf Helgoland - Ber. dt. wiss. Kommn Meeresforsch. 9, 66-69.

Hagmeier, A., 1951. Notiz über die Biologische Anstalt Helgoland nach dem Kriege.-Zool Anz. $146,130-133$,

Hagmeier, E., 1990. Die Arbeit der Biologischen Anstalt: "Meeresforschung für eine gesunde Nordsee". In: Helgoland, 100 Jahre Deutsch. Ed. by H. P. Rickmers \& H. Huster. Niederelbe Verl., Otterndorf, $45-52$.

Harms, J., 1993. Check list of species (algae, invertebrates and vertebrates) found in the vicinity of the island Helgoland (North Sea, German Bight) - review of recent recordings - Helgoländer Meeresunters. $47,1-34$

Heincke, F., 1894. Die Biologische Anstalt aut Helgoland und ihre latigkeit im Jahre 1893 - Wiss. Meeresunters. 1, 1-33.

Heincke, F., 1897. Die Thätigkeit der Kgl. Bioloqischen Anstalt auf Helqolạnd in den Jahren 1894 bis 1896. - Wiss. Meeresunters, 2, 537-579.

Heincke, F., 1905. Bericht über die Tätiakeit im Etatsiahre 1902 - Ber. Beteil Dtl. int. Meeresforsch. $1,29-34$. 
Heincke, F., 1906. Die Arbeiten der Kgl. Biologischen Anstalt auf Helgoland im Interesse der internationalen Meeresforschung. - Ber. Beteil. Dtl. int. Meeresforsch. 3, 51-93.

Heincke, F., 1918. Die Biologische Anstalt auf Helgoland 1892-1917. - Naturwissenschaften 6, $569-573$.

Kinne, O., 1971. Gastforschung und Kursusbetreuung an der Biologischen Anstalt Helgoland. In: Tagungsführer zur 65. Jahresversammlung der Deutschen Zoologischen Gesellschaft, 2-6.

Kornmann, O. \& Sahling, P.-H., 1983a. Meeresalgen von Helgoland, Benthische Grün-, Braun- und Rotalgen. Biol. Anst. Helg., Hamburg, 289 pp. (Helgoländer wiss. Meeresunters. 29, 1-289; veränd. Neudruck).

Kornmann, P. \& Sahling, P.-H., 1983b. Meeresalgen von Helgoland, Ergänzung. - Helgoländer Meeresunters. 36, 1-65.

Martens, P., 1978. Contribution to the hydrographical structure of the eastern German Bight. Helgoländer wiss. Meeresunters. 31, 414-424.

Mielck, W., 1925. Bericht über die Untersuchungen der Biologischen Anstalt auf Helgoland. - Ber. dt. wiss. Kommn Meeresforsch. 1, 11-36.

Mielck, W., 1926. Die Arbeiten der Biologischen Anstalt auf Helgoland. - Ber. dt. wiss. Kommn Meeresforsch. 2, 223-244.

Mielck, W., 1930. Die Arbeiten der DWK in der Biologischen Anstalt auf Helgoland. - Ber. dt. wiss. Kommn Meeresforsch. 5, 230-263.

Rickmers, H. P., Röper, C. \& Huster, H., 1986. Helgoland, Schicksal einer Heimat. Niederelbe Verl., Otterndorf, $151 \mathrm{pp}$.

Rickmers, H. P. \& Woosnam, F., 1992. Helgoland - Eine Insel auf dem Weg nach Europa. Niederelbe Verl., Otterndorf, $223 \mathrm{pp}$.

Schultheiß, E. (Hrsg.), 1988. Das alte Helgoland. Worpsweder Verl., $112 \mathrm{pp}$

Werner, P., 1993. Die Gründung der Königlichen Biologischen Anstalt auf Helgoland und ihre Geschichte bis 1945. - Helgoländer Meeresunters. 47 (Suppl.), 1-182 